\title{
Price Concentration: New Evidence from Greek Industries and the Cournot Model
}

\author{
Nicholas Apergis* \\ Department of Financial \& Banking Management \\ University of Piraeus \\ Piraeus, Greece \\ Vasilios Monastiriotis \\ Hellenic Observatory \\ London School of Economics \\ London, $U K$
}

This paper investigates the degree of competitive forces across Greek industries over the period 2000-2011 at the three-digit SIC level. Based on the simple Cournot modeling approach, three alternative models are used to investigate the competitive conditions across industries. The empirical results indicate that the majority of Greek industries, with the exception of the Chemicals industry, operate in non-competitive conditions.

Keywords: Cournot model, Price concentration, Greek industries

JEL Classification: D40; C22

[Revised version: January 2013]

The authors wish to express their gratitude to an anonymous referee of Economic Papers for his/her valuable comments and suggestions that improved the quality of the paper. Needless to say, the usual disclaimer applies.

* Correspondence: Dr. Nicholas Apergis, Professor, Department of Banking \& Financial

Management, University of Piraeus, Tel. +30-2104142429, E-mail: napergis@unipi.gr 


\section{Price Concentration: New Evidence from Greek Industries and the Cournot Model}

\section{Introduction}

The literature in the area of industrial concentration has investigated the association between price and the number of sellers across a number of industries (Caves et al., 1991; Porter, 1993; Wiggins and Maness, 2004). This literature also provides explicit indexes for a variety of variables, including prices and sales (Martin, 2002).

It is well known that increases in concentration are closely (and positively) associated with market power, denoting the increased capacity of a number of firms to affect prices in the marketplace. Moreover, increased levels of concentration on prices provide substantial information about the ability of such firms to harm consumers and competition levels.

The primary goal of this study is to investigate how prices respond as the number of sellers changes across all industries in Greek manufacturing spanning the period 20002011. The reason for selecting the period after 2000 is that following the entrance of the country in the Eurozone, there was a strong abolition of subsidies as well as the easiest access to funding from the banking sector at lower interest rates. The novelty of the paper is that it applies, for the first time the empirical methodological approach relied upon two simple models of competition, i.e. the standard Cournot quantity setting model and a linear association between prices and the number of sellers.

Section 2 surveys the literature on price competition across industries, while Section 3 presents the methodology and data employed. Section 4 reports the empirical results and Section 5 provides concluding remarks.

\section{Literature Review}

Lopez et al. (2002) argue that higher concentration results in higher prices in nearly all industries in the U.S., while Dickson and Sun (2004) through price-concentration equations show that the overall effect of rising concentration eventually leads to lower prices, which indicates that the majority of concentration models in the literature neglect 
the impact of technological improvements. Coricelli and Horvath (2008), by making use of a micro dataset that accounts for the largest part of the CPI index in Slovakia, find that market structure is a significantly important factor of pricing behavior, leading primarily to inflation persistence. According to them, increased levels of competition are not a guarantee that persistence will be reduced, since persistence is usually fed through inertial behaviors induced by the strategic complementarity among price setters.

In other strands of the literature, the empirical research examines the association between market structure and firms' performance in terms of profitability (Bresnahan, 1989; Weiss, 1989), the association between price concentration, profitability and entry attraction (de Juan, 2008; Manuszak and Moul, 2008; Singh and Zhu, 2008), the association between mergers and acquisitions, price concentration and firms' profitability (Doane et al., 2012) and the impact of market structure on certain economic variables, such as TFP (Buccirossi et al., 2011). Finally, Baker (2003), Crandall and Winston (2003) and Werden (2003) open up a debatable discussion regarding the effectiveness of the antitrust institutional environment. They argue that, on average, competition tends to improve economic as well as social welfare by inducing firms to forgo anti-competitive behaviors without any type of intervention by competition authorities. Kee and Hoekmann (2007) investigate the impact of competition policies on industrial profitability in terms of mark-ups. They find no impact running from competition policies to mark-ups.

In addition, the literature discusses a number of factors driving differences in price developments in both the manufacturing and services sectors, pointing out the critical role played by the size of competition. In particular, the main findings denote that services are characterized by a lower degree of international trading and so competitive pressures are weaker there. Nicoletti and Scarpetta (2003) and Faini et al. (2004) argue that the weaker role of competition in services is enhanced by innovative activities, while Cavelaars (2003) and Przybyla and Roma (2005) concentrate primarily on the direct impact of competition on prices and inflation via downward pressures on profit margins and changes in the institutional framework. At the same time, Kalirajan (2000) and Faini 
et al. (2004) show that the degree of price competition varies across industries and countries.

Finally, the literature is characterized by a great lack of studies investigating the market structure across Greek industries. Only two recent studies are dealing with the issue of concentration in the Greek case, those of Bourlakis (1997) and of Rezitis and Kalantzi (2011), with the former study focusing on the food industry and the latter study giving emphasis on identifying the factors which tend to affect the presence of markups. The empirical findings of the former study display the presence of non-competitive conditions within this industry.

\section{The Methodological Approach and Data}

\subsection{The Methodological Approach}

The empirical approach of the paper follows the theoretical specification of the Cournot model used by Wiggins and Maness (2004). In particular, the simple Cournot model is based on a simple linear inverse demand such as: $\mathrm{P}(\mathrm{q})=\mathrm{a}-\mathrm{bq}$ with constant marginal cost, while q represents total industry market output. We also assume $\mathrm{N}$ as the number of sellers within the industry. Based on these simple assumptions, the market price generated by the Cournot model takes the following form:

$\mathrm{P}(\mathrm{N})=(\mathrm{a}+\mathrm{cN}) /(\mathrm{N}+1)$

According to (1), there is a linear relationship between prices and the inverse of the number of sellers.

One of the assumptions of the Cournot model is that the $\mathrm{N}$ sellers are considered to be identical, which is a plausible assumption for industries characterized by constant returns to scale. According to Tsaliki and Tsoulfidis (1998) and Segoura (1998), this is the case for the majority of Greek industries. In empirical terms, the issue is examined by taking into consideration the number of competitors as a key variable determining the competitiveness of prices. To this end, a proxy for this variable in our case is the use of the Herfindahl Hirschman Index (HHI) for each industry (Ellison et al., 1997). We also include a trend in our model to take into account the fact that manufacturing costs of 
more recently developed products are higher due to the more advanced technology involved.

\subsection{Data}

The sample consists of monthly data spanning the period 2000-2011 on price indexes for all Greek manufacturing industries. Data on sectoral prices, proxied by the Consumer Price Index sectoral indexes $(1995=100)$, are obtained from Datastream. Data on the number of sellers in each industry are obtained from the Independent Statistical Greek Committee (ISGC). Market shares needed to construct the HHI are measured as the firms' sales over the industry sales, with sales data also obtained from the ISGC as well.

The categories of indexes covered are: oil \& gas, chemicals, basic resources, construction materials, industrial goods, food \& beverages, and personal \& household goods. Our sample data are based on 3-digit SIC classified firms. Finally, the Eviews software assisted the empirical analysis.

\section{Empirical Analysis}

To avoid any endogeneity problem, the methodology of IV least squares is used. For the empirical purposes of the study we estimate the following versions of the Cournot model:

Model (1): $\mathrm{P}_{\mathrm{t}}=\mathrm{a}+\mathrm{b}\left[1 /\left(\mathrm{N}_{\mathrm{t}}+1\right)\right]+\mathrm{c} \mathrm{HHI}_{\mathrm{t}}+\mathrm{d}$ TREND

Model (2): $\mathrm{P}_{\mathrm{t}}=\mathrm{a}+\mathrm{b} \mathrm{N}_{\mathrm{t}}+\mathrm{c} \mathrm{HHI}_{\mathrm{t}}+\mathrm{d}$ TREND

Model (3): $\mathrm{P}_{\mathrm{t}}=\mathrm{a}+\mathrm{b} \mathrm{N}_{\mathrm{t}}+\mathrm{c}\left[1 /\left(1+\mathrm{N}_{\mathrm{t}}\right)\right]+\mathrm{d} \mathrm{HHI}_{\mathrm{t}}+\mathrm{d}$ TREND

The results are reported in Table 1. The diagnostics show that all three alternative models are free of serial correlation and functional misspecification. The empirical findings show that in terms of Model (1), prices across industries are associated with the inverse of the number of sellers, as predicted by the Cournot model. The coefficient of $1 /(\mathrm{N}+1)$ across all, but one, industries indicate weak declines when the number of sellers increase; in other words, prices do not decline rapidly once the competition increases in these industries, implying the absence of strong competition forces. The worst case in terms of absence of competition is in the food \& beverages industry. The exception is 
with the Chemicals industries, where the competition is strong, supported by a rapid decline in prices when the number of sellers increases. The HHI index across all industries, except in Chemicals, is positive and statistically significant, indicating a small effect on prices coming from other competitors, while decreasing concentration leads to price reductions. In terms of the other two specifications, i.e. Model (2) and Model (3), the estimations generate similar results, which confirm the absence of strong competitive forces in all industries, except the Chemicals industry. Finally, we reran the models without including the trend variable (this point was raised by a referee) and, although we had quantitative differences, the new results (available upon request) did not alter the main conclusions reached above. 
Table 1. Cournot Regressions

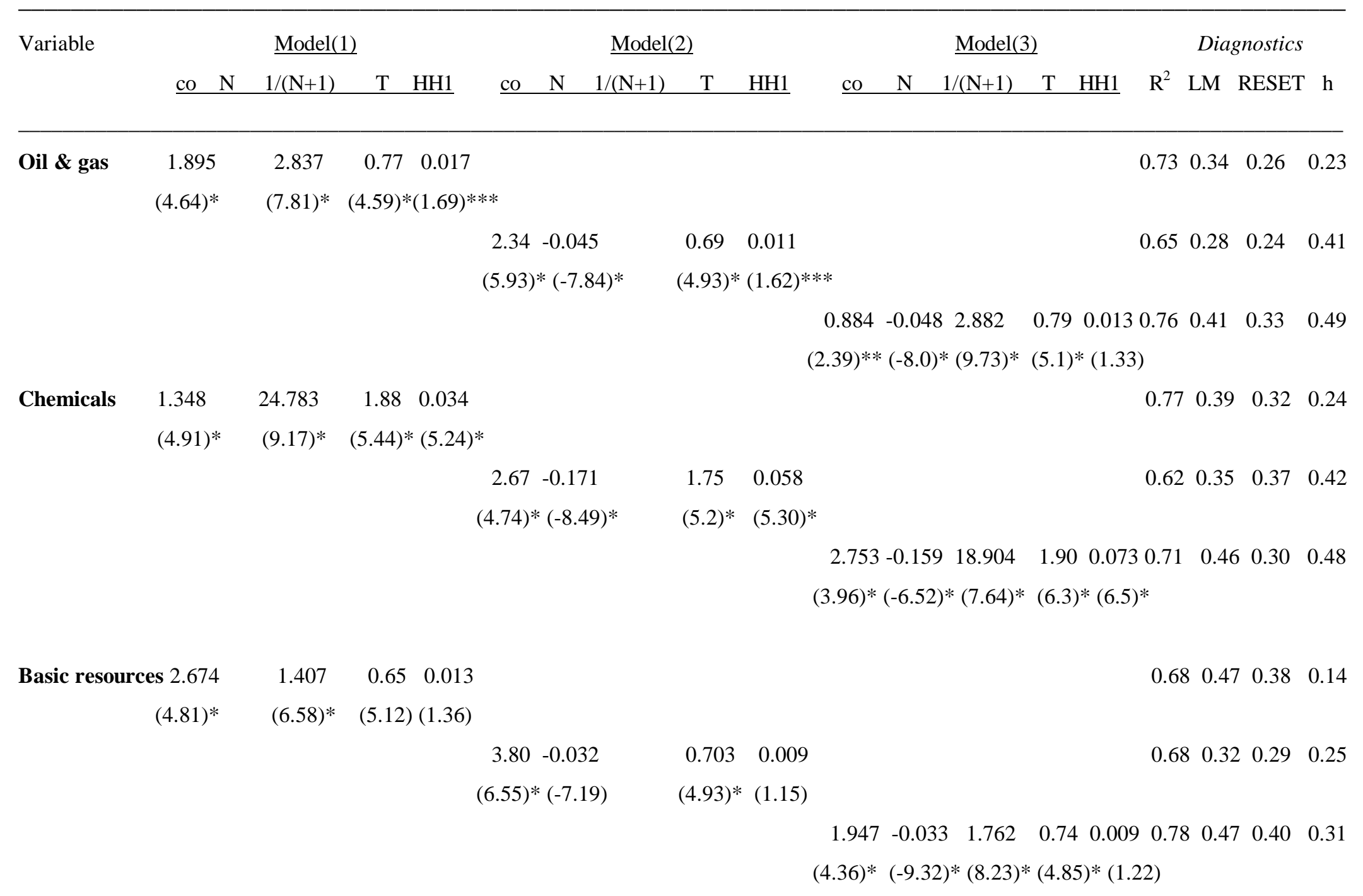




\section{Table 1 continued}

\begin{tabular}{|c|c|c|c|c|c|c|c|c|c|c|c|c|c|c|c|c|}
\hline \multirow[t]{2}{*}{ Variable } & \multicolumn{4}{|c|}{$\underline{\operatorname{Model}(1)}$} & \multicolumn{4}{|c|}{$\underline{\text { Model(2) }}$} & \multicolumn{4}{|c|}{$\underline{\operatorname{Model}(3)}$} & \multicolumn{4}{|c|}{ Diagnostics } \\
\hline & $\underline{\text { co }} \mathrm{N}$ & $1 /(\mathrm{N}+1)$ & $\mathrm{T}$ & $\mathrm{HH} 1$ & co $\mathrm{N}$ & $1 /(\mathrm{N}+1)$ & $\mathrm{T}$ & $\mathrm{HH} 1$ & $\underline{\mathrm{co}}$ & $\mathrm{N}$ & $1 /(\mathrm{N}+1)$ & $\mathrm{T} \quad \mathrm{HH} 1$ & $\mathrm{R}^{2}$ & LM I & RESET & $\mathrm{h}$ \\
\hline \multicolumn{17}{|l|}{ Construction } \\
\hline \multirow[t]{3}{*}{ materials } & $\begin{array}{c}1.981 \\
(5.38)^{*}\end{array}$ & $\begin{array}{l}1.449 \\
(6.58)^{*}\end{array}$ & $\begin{array}{c}0.89 \\
(5.25)\end{array}$ & $\begin{array}{c}0.013 \\
*(1.58) * *\end{array}$ & & & & & & & & & 0.71 & 0.39 & 0.32 & 0.22 \\
\hline & & & & & $\begin{array}{r}1.63-0 . \\
(6.11)^{*}(-)\end{array}$ & 28 & $\begin{array}{l}0.804 \\
(4.86) *\end{array}$ & $\begin{array}{c}0.007 \\
*(1.95)^{* *}\end{array}$ & & & & & 0.69 & 0.30 & 0.44 & 0.39 \\
\hline & & & & & & & & & $\begin{array}{l}1.67 \\
(2.54) *\end{array}$ & $\begin{array}{l}-0.033 \\
* *(-9.7\end{array}$ & $\begin{array}{l}31.327 \\
7)^{*}(8.6)^{*}\end{array}$ & $\begin{array}{l}0.750 .009 \\
(5.4)^{*}(1.14)\end{array}$ & 0.74 & 0.45 & 0.37 & 0.51 \\
\hline \multirow[t]{3}{*}{ Industrial gooc } & $\begin{array}{l}\text { ds } 4.672 \\
\quad(5.13)^{*}\end{array}$ & $\begin{array}{c}1.384 \\
(7.24)^{*}\end{array}$ & $\begin{array}{l}0.77 \\
(4.11)\end{array}$ & $\begin{array}{c}0.012 \\
*(1.38)\end{array}$ & & & & & & & & & 0.76 & 0.38 & 30.54 & 0.15 \\
\hline & & & & & $\begin{array}{c}5.15-0 \\
(5.36) *\end{array}$ & & $\begin{array}{l}0.658 \\
(4.36)^{*}\end{array}$ & $\begin{array}{c}0.011 \\
*(1.94)^{* *}\end{array}$ & & & & & 0.68 & 0.37 & $\begin{array}{ll}7 & 0.45\end{array}$ & 0.31 \\
\hline & & & & & & & & $(4$ & $\begin{array}{l}4.12 \\
4.83)^{*}\end{array}$ & $\begin{array}{l}-0.033 \\
(-8.56)\end{array}$ & $\begin{array}{l}1.894 \\
6) *(9.14)\end{array}$ & $\begin{array}{l}0.530 .014 \\
(5.4)^{*}(1.2)\end{array}$ & 0.79 & 0.49 & 90.61 & 0.29 \\
\hline \multicolumn{17}{|l|}{ Food \& } \\
\hline beverages & $\begin{array}{c}2.553 \\
(4.91)^{*}\end{array}$ & $\begin{array}{l}0.518 \\
(7.42)^{*}\end{array}$ & $\begin{array}{c}0.84 \\
(5.27)\end{array}$ & $\begin{array}{c}0.004 \\
*(1.28)\end{array}$ & & & & & & & & & 0.69 & 0.32 & $2 \quad 0.30$ & 0.20 \\
\hline & & & & & $\begin{array}{r}3.15-0.0 \\
(5.34) *(-\end{array}$ & $\begin{array}{l}9 \\
36)^{*}\end{array}$ & $\begin{array}{l}0.764 \\
4.93)^{*}\end{array}$ & $\begin{array}{l}0.008 \\
(1.11)\end{array}$ & & & & & 0.60 & 0.29 & $\begin{array}{ll}9 & 0.31\end{array}$ & 0.37 \\
\hline & & & & & & & & & $\begin{array}{r}1.90 \\
(5.28) *\end{array}$ & $\begin{array}{l}-0.014 \\
(-6.4)^{3}\end{array}$ & $\begin{array}{l}40.308 \\
*(6.28) *\end{array}$ & $\begin{array}{c}0.680 .012 \\
(4.5)^{*}(1.38)\end{array}$ & 0.62 & 0.35 & $5 \quad 0.31$ & 0.42 \\
\hline
\end{tabular}


This is the peer reviewed version of an article published in final form at http://doi.org/10.1111/1759-3441.12017. This article may be used for non-commercial purposes in accordance with Wiley Terms and Conditions for Self-Archiving at http://olabout.wiley.com/WileyCDA/Section/id-820227.html\#terms 
This is the peer reviewed version of an article published in final form at http://doi.org/10.1111/1759-3441.12017. This article may be used for non-commercial purposes in accordance with Wiley Terms and Conditions for Self-Archiving at http://olabout.wiley.com/WileyCDA/Section/id-820227.html\#terms 
Table 1 continued

\begin{tabular}{|c|c|c|c|c|c|c|c|c|c|c|c|c|c|c|c|c|c|}
\hline \multirow[t]{2}{*}{ Variable } & \multicolumn{5}{|c|}{ Model(1) } & \multicolumn{5}{|c|}{$\underline{\operatorname{Model}(2)}$} & \multicolumn{5}{|c|}{ Model(3) } & \multicolumn{2}{|r|}{ Diagnostics } \\
\hline & $\mathrm{co}$ & $\mathrm{N}$ & $1 /(\mathrm{N}+1)$ & $\mathrm{T}$ & $\mathrm{HH} 1$ & $\underline{\mathrm{co}}$ & $\mathrm{N}$ & $1 /(\mathrm{N}+1)$ & $\mathrm{T}$ & $\mathrm{HH} 1$ & co & $\mathrm{N}$ & $1 /(\mathrm{N}+1)$ & $\mathrm{T}$ & $\mathrm{HH} 1$ & $\mathrm{R}^{2}$ & LM RESET $h$ \\
\hline
\end{tabular}

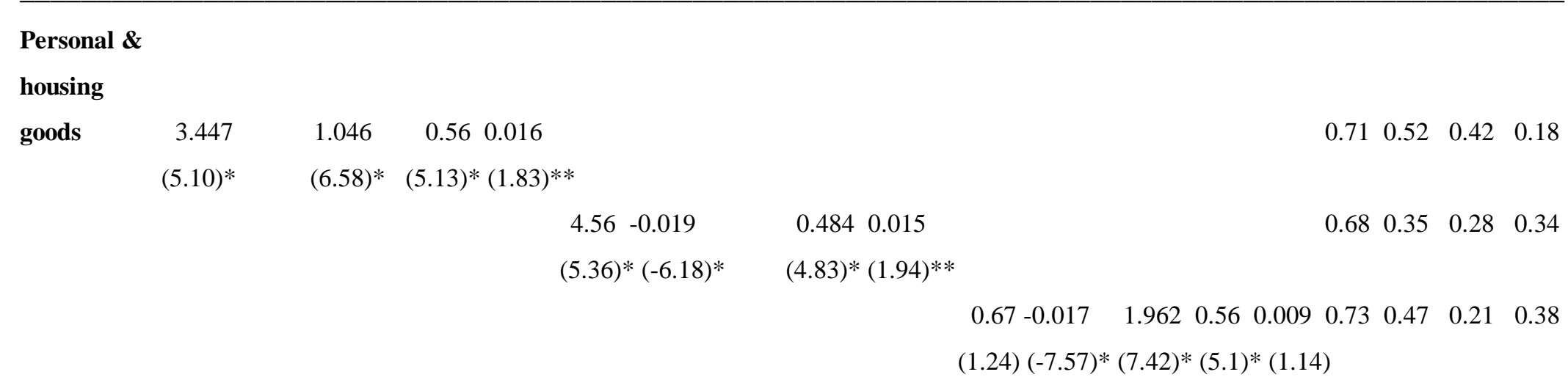

Notes: co denotes the constant term of the regression and T denotes the TREND variable. Figures in parentheses denote t-statistics. LM is a serial correlation test, while RESET is a model functional misspecification test. Figures for the the LM and RESET tests denote p-values. Finally, Sargan test $(\mathrm{h})$ investigates the validity of instruments used. Figures for the h test denote p-values. The instruments used are: for Model (1) specification = constant, 1/[N(-1)+1], [1/(N(-2)+1]. HHI(-1), HHI(-2), HHI(-3). For Model (2) specification = constant, N(-1), N(-2), N(-3), HHI(-1), HHI(-2), HHI(3), and for Model (3) specification = constant, N(-1), N(-2), [1/(N(-1)+1], [1/(N(-2)+1], HHI(-1), HHI(-2), HHI(-3).

$* * *, * * *$ statistical significant at $1 \%, 5 \%$, and $10 \%$, respectively. 
This is the peer reviewed version of an article published in final form at http://doi.org/10.1111/1759-3441.12017. This article may be used for non-commercial purposes in accordance with Wiley Terms and Conditions for Self-Archiving at http://olabout.wiley.com/WileyCDA/Section/id-820227.html\#terms 


\section{Conclusions}

This empirical study examined for the first time the degree of price competition across Greek manufacturing industries spanning the period 1980-2011 through the methodology of a simple Cournot model. The analysis used data covering seven industrial classifications. The empirical findings showed that the majority of Greek industries are characterized by the lack of strong competitive forces. These empirical findings seem to nicely justify the presence of strong inflation persistence in the majority of industries in Greek manufacturing (Apergis, 2013).

Given the fact that competitive markets create benefits to the long-run performance of an economy, the implications of the empirical findings are very important, especially for regulatory authorities. More competitive markets could contribute to price reductions and, thus, not only will increase the resilience to economic shocks, but also will facilitate the acceptance of recent austerity plans imposed on the Greek economy by the Troika.

A potential strand of extension would be to employ a different analysis. In particular, the research attempt could explicitly consider the introduction of brand-name products. The reason is that a number of industries are characterized by substantial product differentiation, since a quite large number of products achieve brand recognition, thus, generating important differences across branded entries and in terms of competitive forces. Another potential extension of this empirical study will be the comparison between the benefits and the costs of introducing competition laws and enforcing competition policies to perform a welfare analysis. It would be also interesting to expand the database to include other countries, both developed and less developed. 


\section{REFERENCES}

Apergis, N. (2013, forthcoming) 'Inflation persistence in Greece: new evidence across industries', Panoeconomicus.

Baker, J. B. (2003) 'The case of antitrust enforcement', Journal of Economic Perspectives, 17, 2750-72.

Bourlakis, C. A. (1997) 'Profitability of survival and firm growth in Greek food industry, 1966-1986', Working Paper, Athens: Center of Planning and Economic Research.

Bresnahan, T. (1989) 'Empirical studies of industries with market power', in R. Schmalensee and R. D. Willig (Eds.), Handbook of Industrial Organization, Vol. 2, North-Holland, Amsterdam.

Buccirossi, P., Ciari, L., Duso, T., Spagnolo, G. and Vitale, C. (2011) 'Competition policy and productivity growth: an empirical assessment', Dusseldorf Institute for Competition Economics, Working Paper No. 22.

Cavelaars, P. (2003) 'Does competition enhancement have permanent inflation effects?', Kyklos, 56, 69-94.

Caves, R. E., Whinston, M. D. and Hurwitz, M. A. (1991) 'Patent expiration, entry and competition in the U.S. pharmaceutical industry', Brookings Papers on Economic Activity: Microeconomics, 1-66.

Coricelli, F. and Horvath, R. ((2008) 'Price setting and market structure: an empirical analysis of micro data', William Davidson Institute Working Paper, No. 938, University of Michigan.

Crandall, R. W. and Winston, C. (2003) 'Does antitrust policy improve consumer welfare? Assessing the evidence', Journal of Economic Perspectives, 17, 3-26.

de Juan, R. (2008) 'Competition in local markets: some evidence from the Spanish retail banking market', Review of Industrial Organization, 32, 145-62.

Dickson, V. A. and Sun, Y. (2004) 'Revisiting the price effects of rising concentration in U.S. food manufacturing,, Journal of Agricultural and Food Industrial Organization, 2, 15-27. 
Doane, M. J., Froeb, L. M., Werden, G. J. and Zimmer, D. M. (2012) 'Pricing and market concentration: a new estimation strategy', Vanderbilt Law and Economic Working Paper Series, No. 12-14, Vanderbilt University.

Ellison, S. F., Cockburn, I., Griliches, Z. and Hausman, J. (1997) 'Characteristics of the demand for pharmaceutical: an examination of four cephalosporins', Rand Journal of Economics, 28, 426-46.

Faini, R., Haskel, J., Navaretti, G. B., Scarpa, C. and Wey, C. (2004) 'Contracting Europe's decline: do product markets reforms help?', Mimeo.

Kalirajan, K. (2000) 'Restrictions on trade in distribution services', Productivity Commission Staff Research Paper, Canberra.

Kee, H. L. and Hoekman, B. (2007) 'Imports, entry and competition law as market disciplines', European Economic Review, 51, 831-58.

Lopez, R. A., Azzam, A. D. and Liron-Espana, C. (2002) 'Market power and/or efficiency: a structural approach', Review of Industrial Organization, 20, 115-26.

Manuszak, M. and Moul, C. (2008) 'Prices and endogenous market structure in office supply superstores', Journal of Industrial Economics, 56, 94-112.

Martin, S. (2002) Advanced Industrial Economics, $2^{\text {nd }}$ Edition, Malden, MA: Blackwell.

Nicoletti, G. and Scarpetta, S. (2003) 'Regulation, productivity and growth: OECD evidence', OECD Economics Department Working Paper, No.347.

Porter, R. (1983) 'A study of cartel stability: the joint executive committee, 1880-1886', Bell Journal of Economics, 14, 301-14.

Przybyla, M. and Roma, M. (2005) 'Does product market competition reduce inflation? Evidence from EU countries and sectors', ECB Working Paper, No. 453.

Rezitis, A. N. and Kalantzi, M. A. (2011) 'Investigating market structure of the Greek manufacturing industry: a Hall-Roeger approach', Atlantic Economic Journal, 39, $383-400$.

Segoura, I. (1998) 'Return to scale and external economies: empirical evidence from Greek two-digit manufacturing industries', Applied Economic Letters, 5, 485-90.

Singh, V. and Zhu, T. (2008) 'Pricing and market concentration in oligopoly markets', Marketing Science, 27, 1020-35. 
This is the peer reviewed version of an article published in final form at http://doi.org/10.1111/1759-3441.12017. This article may be used for non-commercial purposes in accordance with Wiley Terms and Conditions for Self-Archiving at http://olabout.wiley.com/WileyCDA/Section/id-820227.html\#terms

Tsaliki, P. and Tsoulfidis, E. (1998) 'Alternative theories of competition: evidence from Greek manufacturing' International Review of Applied Economics, 12, 187-204.

Weiss, L. W. (1989) Concentration and Price, Cambridge, MA: MIT Press.

Werden, G. (2003) 'The 1982 merger guidelines and the ascent of the hypothetical monopolist paradigm', Antitrust Law Review, 71, 253-69.

Wiggins, S. N. and Maness, R. (2004) 'Price competition in pharmaceuticals: the case of anti-infectives', Economic Inquiry, 42, 247-63. 